\title{
Soil Test Crop Response Based Fertilizer Prescription for Urd Grown on Mollisol of Uttarakhand, India
}

\author{
Varun Tripathi ${ }^{2}$, Ajaya Srivastava ${ }^{1}$, S.P. Gangwar ${ }^{2}$ and R.K. Singh $^{3}$ \\ ${ }^{1}$ Department of Soil Science, College of Agriculture, G.B. Pant University of Agriculture and \\ Technology, Pantnagar, Uttarakhand, 263145, India \\ ${ }^{2}$ Research \& KVK, Lohaghat, Champawat, Uttarakhand, India \\ ${ }^{3}$ KVK, Gaina, Pithoragarh, Uttarakhand, India \\ *Corresponding author
}

\begin{tabular}{|l|}
\hline Ke y w o r d s \\
$\begin{array}{l}\text { Soil test, Crop } \\
\text { response, Fertilizer, } \\
\text { Urd growth }\end{array}$ \\
\hline Article Info \\
\hline $\begin{array}{l}\text { Accepted: } \\
\text { 04 June 2018 } \\
\text { Available Online: } \\
\text { 10 July 2018 }\end{array}$ \\
\hline
\end{tabular}

\section{Keywords}

Soil test, Crop response, Fertilizer,

Article Info

Accepted:

Available Online:

10 July 2018

\section{A B S T R A C T}

A field experiment was conducted during spring 2014-2015 at the Norman E. Borlaug Crop Research Centre of the G.B. Pant University of Agriculture and Technology, Pantnagar $\left(29^{\circ} \mathrm{N}\right.$ latitude and $79^{\circ} 29^{\prime} \mathrm{E}$ longitude), as per technical programme of All India Coordinated Research Project on the soil test crop response correlation. The experiment was conducted in "two-phases". In the first phase soil fertility gradient was developed by dividing the experimental field into "three strips" and applying graded doses of fertilizers in them (Strip I no fertilizer), Strip II $\left(100,100\right.$ and $100 \mathrm{~kg} / \mathrm{ha} \mathrm{N}, \mathrm{P}_{2} \mathrm{O}_{5}$ and $\mathrm{K}_{2} \mathrm{O} / \mathrm{ha}$ ) respectively, and strip III $\left(200,200\right.$ and $200 \mathrm{~kg} \mathrm{~N}, \mathrm{P}_{2} \mathrm{O}_{5}$ and $\left.\mathrm{K}_{2} \mathrm{O}\right)$ respectively and growing of exhaust crop sorghum (var. Pant Chari-7). In the second phase, i.e. next season test crop Urd (var. Pant Urd-7) was grown. Response to "select" combinations of "three-levels" of FYM $(0,5$ and $10 \mathrm{t} / \mathrm{ha})$, "four-levels" of nitrogen $(0,10,20$ and 30 $\mathrm{kg} / \mathrm{ha}$ ), four levels of phosphorus $(0,20,40$ and $60 \mathrm{~kg} / \mathrm{ha})$ and four levels of potassium $(0$, 30,60 and $90 \mathrm{~kg} / \mathrm{ha}$ ) at different fertility levels of Urd bean was studied. The values of the organic carbon, Alkaline $\mathrm{KMnO}_{4}$ extractable $\mathrm{N}$, Olsen's $\mathrm{P}$ and Neutral normal ammonium acetate extractable $\mathrm{K}$ in the experimental field ranged between $0.22-0.75$ per cent, 112-178 $\mathrm{kg} / \mathrm{ha}, 12.20-20.02 \mathrm{~kg} / \mathrm{ha}$ and $100.2-178.85 \mathrm{~kg} / \mathrm{ha}$, respectively. In the present investigation the total straw yield ranged from $64.93-233.76 \mathrm{q} / \mathrm{ha}$ and total grain yield ranged from 17.26-181.72q/ha. The nutrient requirement for production of one quintal of Urd bean grain was found to be $3.18 \mathrm{~kg}$ of nitrogen, $0.63 \mathrm{~kg}$ of phosphorus and $2.54 \mathrm{~kg}$ of potassium. The percent contribution of nitrogen, phosphorus and potassium was 38.15 , 72.61 and 36.51, from soil, whereas from other sources as FYM was 78.34, 17.05, 38.21; chemical fertilizer 169.81, 17.19 and 94.98 and conjoint use of chemical fertilizer with FYM 187.65, 15.88 and 96.08 concerning NPK respectively. With the help of these data fertilizer recommendations at different yield targets and soil test value can be calculated. Findings from present study can successfully be utilized for the larger parts of Tarai region of Uttarakhand as an effective guide for efficient and balanced fertilizer recommendations. 


\section{Introduction}

Fertilizer is among the costliest inputs in agriculture and the use of the right amounts of fertilizer is fundamental for farm profitability and environmental protection (Kimetu et al., 2004). To enhance farm profitability under different soil-climate conditions, it is necessary to have information on optimum doses for crops. Traditionally, to determine the optimum fertilizer doses of the most appropriate method is to apply the fertilizer on the basis of a soil test and crop response studies. During 1956-57 the semi-quantitative soil test calibrations were evolved and advocated for its use. Subsequently, in India, the quantitative refinements in the fertilizer recommendations based on the soil and plant analysis were made during 1967-68 through the All India Coordinated Research Project for Investigation on Soil test crop response correlation (STCRC). The ICAR project on soil test crop response correlation used the targeted yield approach to develop a relationship between crop yields on the one hand and soil test values and fertilizer inputs on the other. Black gram (Vigna mungo L.) is one of the major rainy season pulse crop also known as Urd or Mash grown throughout India. It is consumed in the form of "dal". In India, It is grown on 2.70 million hectare area with the production of 0.94 million tonnes. The yield potential of black gram is very low because of the fact that the crop is mainly grown in rain-fed conditions with poor management practices and also due to various physiological, biochemical as well as inherent factors associated with the crop. Apart from the genetic makeup, the physiological factor, namely insufficient portioning of assimilates, poor setting due to the flower abscission and lack of nutrients during critical stages of crop growth, coupled with a number of diseases and pests (Mahala et al., 2001) were the reasons for the poor yield. India is the largest producer as well as consumer of black gram.
Black gram accounts for about ten percent of India's total pulse production. It is cultivated in India in about 3.24 million hectares with average productivity at $469 \mathrm{~kg} / \mathrm{ha}$. The production of the black gram was $1.82 \mathrm{mt}$ in 2010-11, with around 78 percent production of Kharif season and $0.42 \mathrm{mt}$ from Rabi season. The average production in India over the last decade was $1.4 \mathrm{mt}$ per annum. The major black gram producing a state in India is Andhra Pradesh, Maharashtra, Madhya Pradesh, Tamil Nadu and Uttar Pradesh. Bihar has the highest productivity with $800 \mathrm{~kg} / \mathrm{ha}$ followed by Uttarakhand $(786 \mathrm{~kg} / \mathrm{ha})$ and West Bengal (714 kg/ha). Andhra Pradesh is the largest producing state contributing for about 19 percent of total country's output, followed by Maharashtra and Madhya Pradesh, with 20 percent and 13 percent respectively. India imported $0.71 \mathrm{mt}$ of black gram in 2009-10, showing a rise of 60 percent over the consumption of the previous year. India imports nearly 85 per cent of black gram requirements of Myanmar followed by Singapore and Thailand. Application of fertilizer by the farmer without information on soil fertility status and nutrient requirement of crop, soil and crop will be affected adversely. Soil testing is one of the best scientific means for quick and reliable estimation of soil fertility status. A greater economy in fertilizer use can be made, if fertilizers are applied on the basis of the soil test. This practice ensures balanced fertilization, higher yield and more profitability. The fertility gradient field experimental technique of (Ramamoorthy et al., 1967) for evolving soil test and targeted yield based fertilizer recommendation (STCR) to crop is unique in the sense that response of crops to applied nutrient is studied on representative soils, where variations in soil fertility had been created earlier by applying different amount of fertilizer nutrients to the preceding crop. The approach circumvents the effect of soil heterogeneity, management practices and climatic conditions on the 
response through native and fertilizer nutrients. Fertilizer recommendation based on soil test crop response correlation (STCR) concept is more quantitative, precise and meaningful because the combined use of soil and plant analysis is involved in it. While developing the STCR targeted yield equation contribution of nutrients from the soil, fertilizer and organics is taken into consideration. Similarly, by taking these into consideration nutrient requirement (NR) to produce a quintal of grain or any economic produce are considered. It gave a real balance between applied nutrients and the available nutrients already present in the soil. Besides, it takes into account the farmer's ability to invent for raising the crops. Besides balanced nutrition of growing crops, this approach gives due consideration to soil fertility and strikes a real balance between the nutrients already available in the soil and those required by the crops to achieve a predetermined yield target.

\section{Materials and Methods}

A field experiment was carried out at the Norman E. Borlaug's Crop Research Centre College of Agriculture, G.B. Pant University of Agriculture and Technology, Pantnagar India to develop a scientific basis for prescribing fertilizer recommendations for urd (Vigna mungo) as the test crop. The soil of the experimental site was clay loam in texture, $\mathrm{pH}$ was 7.80 with the high level of organic carbon, medium available potassium, low available nitrogen, very low phosphorus.

\section{Treatment structure, soil and plant analysis}

The field experiment viz., fertility gradient experiment with exhaustive fodder sorghum (var. Pant Chari-7), the test crop experiment the test verification with Urd (Pant Urd-31) were conducted at Norman E. Borlaug's Crop Research Centre College of Agriculture, G.B. Pant University of Agriculture and
Technology, Pantnagar India on Aquic Hapludoll during 2014-15.

The details of the crops and important cultural operations carried out in the experiment are described below. The treatment structure and layout design as followed in the All India Coordinated Research Project for investigations on soil test crop response correction (AICRP-STCR) based on "Inductive cum Targeted Yield Model" was adopted for the experimentation.

\section{Gradient experiment}

Prior to the test crop experimentation, the fertility gradient experiment was conducted by dividing the experimental field into three rectangular strips (Low, medium and high). The layout of the experiment was based on the fertility gradient approach developed by (Ramamoorthy et al., 1967). The needed variation in soil fertility levels was deliberately created by dividing the field into three equal strips (Low, Medium and High) which were applied with three fertility gradient doses of NPK (0X, X, 2X). These were applied in Low, medium and high strip respectively. An exhaustive crop of fodder sorghum was grown to enable the applied fertilizer to undergo a transformation in the soil by plant and microbes. Fodder sorghum was harvested and recorded the fodder yield was recorded similarly, soil samples were also collected and analyzed to check the fertility gradient developed.

\section{Test crop experiment}

After the establishment of fertility gradient in the experimental field, each fertility strip was divided into "three blocks" to impose "three levels" of FYM $\left(F_{1}-0.00, F_{2}-5.00\right.$ and $F_{3}-$ $\left.10.00 \mathrm{t} \mathrm{ha}^{-1}\right)$. Each block was again divided into eight-plots so that totals 72 plots were made. Before applying the FYM and NPK, 
soil samples $(0-15 \mathrm{~cm})$ from all these plots were collected and analyzed for alkaline$\mathrm{KMnO}_{4}-\mathrm{N}$ outlined by (Subbaiah et al., 1956); Olsen's-P and $\mathrm{NH}_{4} \mathrm{OAC}-\mathrm{K}$ method as described by (Jackson 1973). The experiment was laid out in fractional factorial design comprising of 21 treated plots and 3 control treatments in each strip covering totally 72 plots which was composed of 63 treated plots and 9 control plots and Urd crop was tested with four levels of $\mathrm{N}\left(0,10,20\right.$ and $\left.30 \mathrm{~kg} \mathrm{ha}^{-1}\right)$ $\mathrm{P}\left(0,20,40\right.$ and $\left.60 \mathrm{~kg} \mathrm{ha}^{-1}\right)$ and $\mathrm{K}(0,30,60$ and $\left.90 \mathrm{~kg} \mathrm{ha}{ }^{-1}\right)$. The experiment was conducted as per the approved guidelines of All India Coordinated Research Project (AICRP) on Soil Test Crop Response Correlations (STCR). A half dose of $\mathrm{N}$ fertilizer along with a full dose of $\mathrm{P}$ and $\mathrm{K}$ was applied at Urd sowing and remaining half dose of $\mathrm{N}$ was applied in two splits. At harvest, grain and straw yield was recorded from all the plots, and expressed in $\mathrm{kg} \mathrm{ha}$. Representative plant samples were collected from the test crops, washed thoroughly with running water followed by double distilled water. The plant samples were then dried at $60^{\circ} \mathrm{C}$ to attain a constant weight, ground and analyzed for nitrogen, phosphorus and potassium contents by following standard procedure outlined by (Jackson 1973) and nutrient uptake was computed.

\section{Data computation}

Initial soil data, yield and nutrient uptake by the crop were used for obtaining nutrient required to produce a quintal of grain yield (NR), contribution of nutrients from the soil (\% CS), contribution of nutrients from fertilizers (\% CF) and contribution of nutrients from organic matter (C-FYM) using following formulae.

NR $\left(\mathrm{kg} \mathrm{q}^{-1}\right)=$ Nutrient uptake (NPK) $(\mathrm{kg}$ $\mathrm{ha}^{-1}$ ) by grain + straw Grain yield or any economic produce $\left(\mathrm{q} \mathrm{ha}{ }^{-1}\right)$
\% CS = Nutrient uptake (NPK) $\left(\mathrm{kg} \mathrm{ha}^{-1}\right)$ by grain + straw in control plot Soil test values (Av. NPK) in control plot $\left(\mathrm{kg} \mathrm{ha}^{-1}\right) \times 100$

$\% \mathrm{CF}=\{$ Nutrient uptake by grain + straw in treating plot $\}-\{[$ Soil test values in treated plot] X [\% Contribution (NPK) from soil] 100 Nutrient doses applied in treated plot $\left(\mathrm{kg} \mathrm{ha}^{-1}\right)$ X100

$\% \mathrm{C}-\mathrm{FYM}=\{$ Total uptake of NPK in organic plot $\left.\left(\mathrm{kg} \mathrm{ha}^{-1}\right)\right\}-\{[$ Mean CF of control plot] X [STV in organic plot $\left.\left(\mathrm{kg} \mathrm{ha}^{-1}\right)\right]$ 100 Amount of NPK added through FYM (kg $\mathrm{ha}^{-1}$ ) X100

These basic parameters were transformed into a simple, workable fertilizer adjustment equations for calculating specific yield target based on soil test values following the procedure of (Ramamoorthy et al., 1967).

\section{Results and Discussion}

The range and mean of soil test values and yield of treated and control plots are presented in Table 1. In treated plots grain yield ranged from 51.92 to181.72 with an average yield of $240.06 \mathrm{q} / \mathrm{ha}$. In control plots grain yield ranged from 103.84 to210 with an average of $123.95 \mathrm{q} / \mathrm{ha}$.

\section{Fertilizer without FYM}

Fertilizer recommendations as per the need of nutrients for the targeted yield are based on the initial soil test values. Grain yield ranged from 2.59-23.37 q ha ${ }^{-1}$ therefore 20, 25 and 30 $\mathrm{q} \mathrm{ha}^{-1}$ yield was selected to calculate nutrient requirements for a target yield of Urd bean without the use of FYM. The STV ranged for nitrogen are 31.36-134.85, for phosphorus 8.72 to $41.04 \mathrm{~kg} / \mathrm{ha}$ and for potassium 32.48 to 198.24. Therefore, soil test value was considered within that range to calculate the nutrient requirements for target yield without 
the conjoint use of FYM. To achieve $30 \mathrm{q} \mathrm{ha}^{-1}$ yield target, $39.33 \mathrm{~kg}$ nitrogen $\mathrm{ha}^{-1}$ was needed at the soil test value of $75 \mathrm{~kg}$ alkaline $\mathrm{KMnO}_{4}$ $\mathrm{N}$ ha $^{-1}$ nitrogen, whereas for the same yield target at $100 \mathrm{~kg}$ soil test value for alkaline $\mathrm{KMnO}_{4}-\mathrm{N} \mathrm{ha}^{-1}$, $33.71 \mathrm{~kg}$ of nitrogen as fertilizer was required (Table 2 and 3). Further, if the soil tests value of nitrogen reaches to $125 \mathrm{~kg} \mathrm{ha}^{-1}$ then to reach the same yield target $28.09 \mathrm{~kg} \mathrm{~N} \mathrm{ha}^{-1}$ needed. Further, if the soil test value of nitrogen reaches to 150 $\mathrm{kg} / \mathrm{ha}$ the fertilizer nitrogen required would be $22.48 \mathrm{~kg} / \mathrm{ha}$ as presented in Table 4 . Similarly, fertilizer phosphorus requirement to targeted yield of $30 \mathrm{q} \mathrm{ha}^{-1}$ at a lower soil test value, i.e. $15 \mathrm{~kg} \mathrm{ha}^{-1}$ of Olsen's phosphorus was 46.58 $\mathrm{kg} \mathrm{ha}^{-1}$. At the soil test, value of $20 \mathrm{~kg}$ of Olsen's $\mathrm{P} \mathrm{ha}^{-1}$ to achieve same yield target (30 $\mathrm{q} \mathrm{ha} \mathrm{h}^{-1}$ ) requirement of fertilizer phosphorus was $25.46 \mathrm{~kg} \mathrm{ha}^{-1}$. However, where the soil test value reaches $25 \mathrm{~kg}$ Olsen's $\mathrm{P} \mathrm{ha}^{-1}$, the fertilizer phosphorus was $4.34 \mathrm{~kg} \mathrm{ha}^{-1}$ needed as presented in (Table 4). The potassium fertilizer requirement for a targeted yield of 30 $\mathrm{q} \mathrm{ha}^{-1}$ where the soil test value of potassium was $100 \mathrm{~kg} \mathrm{ha}^{-1} \mathrm{NH}_{4} \mathrm{OAC}-\mathrm{K}$, and $41.78 \mathrm{~kg}$ fertilizer potassium was required. While at $125 \mathrm{~kg} \mathrm{ha}^{-1}$ and $150 \mathrm{~kg} \mathrm{ha}^{-1}$ soil test values of potassium, need of potassium fertilizer for same yield target were 32.17 and $22.56 \mathrm{~kg}$ $\mathrm{ha}^{-1}$, respectively given in table 4 . Further the need of potassium fertilizer at the soil test value of $175 \mathrm{~kg} / \mathrm{ha}$ was about $12.95 \mathrm{~kg} / \mathrm{ha}$ as presented in table $4, \mathrm{~N}, \mathrm{P}$ and $\mathrm{K}$ requirement also shown in figure 1, 2 and 3 respectively.

\section{Fertilizer requirement of Urd with 10 ton FYM}

Fertilizer recommendations as per the need of nutrients for the targeted yield based on the initial soil test values. Grain yield ranged from 9.0 to $18.2 \mathrm{q} \mathrm{ha}^{-1}$ therefore 20,25 and $30 \mathrm{q}$ $\mathrm{ha}^{-1}$ yields was selected. The STV ranged for nitrogen as 112.3 to 200.6 , for phosphorus
13.0 to 24.24 and for potassium 101.9 to 245.0. Therefore, soil test value considered within that range to calculate the nutrient requirements for target yield with the conjoint use of FYM (10 tones). To achieve $30 \mathrm{q} \mathrm{ha}^{-1}$ yield target, $28.89 \mathrm{~kg}$ nitrogen $\mathrm{ha}^{-1}$ was needed at the soil test value of $75 \mathrm{~kg}$ alkaline $\mathrm{KMnO}_{4}$ $\mathrm{N}$ ha $^{-1}$ nitrogen, whereas for the same yield target at $100 \mathrm{~kg}$ soil test value for alkaline $\mathrm{KMnO}_{4}-\mathrm{N} \mathrm{ha}^{-1}, 23.27 \mathrm{~kg}$ of nitrogen as fertilizer was required. Further, if the soil test value of nitrogen reaches to $125 \mathrm{~kg} \mathrm{ha}^{-1}$ then to reach the same yield target $17.66 \mathrm{~kg} \mathrm{~N} \mathrm{ha}^{-1}$ needed and when the soil test value reaches $150 \mathrm{~kg} / \mathrm{ha}$ the fertilizer nitrogen required at the yield target of $30 \mathrm{q} / \mathrm{ha}$ was $12.04 \mathrm{~kg} / \mathrm{ha}$ as presented in (Table 5) figure 4. Similarly, fertilizer phosphorus requirement to targeted yield of $30 \mathrm{q} \mathrm{ha}^{-1}$ at a lower soil test value, i.e. $15 \mathrm{~kg} \mathrm{ha}^{-1}$ of Olsen's phosphorus was 45.51 $\mathrm{kg} \mathrm{ha}^{-1}$. At the soil test, value of $20 \mathrm{~kg}$ of Olsen's $\mathrm{P}^{-1}$ to achieve same yield target (18 $\mathrm{q} \mathrm{ha} \mathrm{h}^{-1}$ ) requirement of fertilizer phosphorus was $24.39 \mathrm{~kg} \mathrm{ha}^{-1}$ at the soil test value of 25 $\mathrm{kg}$ of Olsen's-P ha- ${ }^{-1}$ the fertilizer phosphorus required was in 3.27 and the fertilizer phosphorus requirement was in negative at the soil test value of $35 \mathrm{~kg} / \mathrm{ha}$ at the same yield target as presented in (Table 5) figure 5. The Potassium fertilizer requirement for a targeted yield of $30 \mathrm{q} \mathrm{ha}^{-1}$ where the soil test value of potassium was $100 \mathrm{~kg} \mathrm{ha}^{-1} \mathrm{NH}_{4} \mathrm{OAc}-\mathrm{K}, 40.79$ $\mathrm{kg}$ fertilizer potassium was required. While at $125 \mathrm{~kg} \mathrm{ha}^{-1}$ and $150 \mathrm{~kg} \mathrm{ha}^{-1}$ soil test values of potassium, need of potassium fertilizer for same yield target were 31.18 and $21.57 \mathrm{~kg}$ $\mathrm{ha}^{-1}$, respectively and at last at the soil test value of $175 \mathrm{~kg} \mathrm{ha}^{-1}$ at the same yield target the fertilizer dose was $11.96 \mathrm{~kg} / \mathrm{ha}$ as presented in (Table 5) and figure 6.

Available Nitrogen extracted by alkaline$\mathrm{KMnO}_{4}$ method of the experimental field varied from 87.89 to $464.12 \mathrm{~kg} \mathrm{~N} \mathrm{ha}^{-1}$ with a mean $251.22 \mathrm{~kg} \mathrm{~N} \mathrm{ha}^{-1}$. 
Table.1 Ranges and averages of yield and soil test value of Urd under different strips

\begin{tabular}{|c|c|c|}
\hline Variable & Range & Mean \\
\hline Organic carbon $(\boldsymbol{\%})$ & $0.68-1.06$ & 0.76 \\
\hline KMnO4-N & $31.36-134.84$ & 63.59 \\
\hline Olsen-P & $12.82-41.03$ & 27.93 \\
\hline NH$_{\mathbf{4}} \mathbf{O A c}-\mathbf{K}$ & $32.48-198.24$ & 85.74 \\
\hline & Grain yield $\left(\mathbf{q} \mathbf{~ h a}^{-\mathbf{1}}\right)$ & \\
\hline Treated plots & $51.92-181.72$ & 240.06 \\
\hline Control plots & $103.84-210$ & 123.95 \\
\hline
\end{tabular}

Table.2 Basic data and fertilizer adjustment equations for urd yield in Mollisol

\begin{tabular}{|c|c|c|c|c|c|}
\hline \multirow{2}{*}{ Nutrients } & \multicolumn{4}{|c|}{ Basic Data } & \multirow{2}{*}{ Fertilizer adjustment equation } \\
\cline { 2 - 5 } & $\begin{array}{c}\mathbf{N R} \\
\left(\mathbf{k g ~ q}^{-\mathbf{1}} \mathbf{)}\right.\end{array}$ & $\mathbf{C}_{\mathbf{S}}(\mathbf{\%})$ & $\begin{array}{c}\mathbf{C}_{\mathbf{F}} \\
\mathbf{( \% )}\end{array}$ & $\begin{array}{c}\mathbf{C}_{\mathbf{F Y M}} \\
\mathbf{( \% )}\end{array}$ & \\
\hline $\mathrm{N}$ & 3.18 & 38.15 & 169.81 & 78.35 & $\mathbf{F N}=1.69 \mathrm{~T}-0.20$ SN-0.42FYM-N \\
\hline $\mathrm{P}_{2} \mathrm{O}_{5}$ & 0.63 & 72.61 & 17.19 & 17.05 & FP=9.09T-10.46 SP-2.45FYM-P \\
\hline $\mathrm{K}_{2} \mathrm{O}$ & 2.54 & 36.51 & 94.98 & 38.21 & FK=3.17T-0.46SK-0.48FYM-K \\
\hline
\end{tabular}

Where, FN, FP, FK $=$ fertilizer $\mathrm{N}, \mathrm{P}_{2} \mathrm{O}_{5}, \mathrm{~K}_{2} \mathrm{O}, \mathrm{kg} \mathrm{ha}^{-1}$;

The NR = Nutrient requirement $(\mathrm{kg})$ to produce one tonne of grain production,

$\mathrm{C}_{\mathrm{S}}=$ Contribution of nutrients from soil nutrient (\%),

$\mathrm{C}_{\mathrm{F}}=$ Contribution of nutrients from applying fertilizer nutrient (\%),

$\mathrm{C}_{\mathrm{FYM}}=$ Contribution of nutrients from applying FYM (\%);

$\mathrm{T}=$ Yield target $\left(\mathrm{t} \mathrm{ha} \mathrm{h}^{-1}\right)$;

SN, SP, SK = Soil available NPK $\left(\mathrm{kg} \mathrm{ha}^{-1}\right)$;

ON, OP, OK = FYM NPK $\left(\mathrm{kg} \mathrm{ha}^{-1}\right)$

Table.3 Fertilizer adjustment equations for urd

\begin{tabular}{|c|c|c|}
\hline Fertilizer dose & With FYM & Without FYM \\
\hline $\begin{array}{c}\text { Nitrogen Dose } \\
\left(\mathrm{Kg} \mathrm{ha}^{-1}\right)\end{array}$ & $\begin{array}{c}\text { FN }=1.69 \mathrm{~T}-0.20 \mathrm{SN}- \\
0.42 \mathrm{FYM}-\mathrm{N}\end{array}$ & FN = 1.87T-0.23 SN \\
\hline $\begin{array}{c}\text { Phosphorus } \\
\text { Dose }\left(\mathrm{kg} \mathrm{ha}^{-1}\right)\end{array}$ & $9.09 \mathrm{~T}-10.46 \mathrm{SP}-2.45 \mathrm{FYM}-\mathrm{P}$ & 8.39T-9.67SP \\
\hline $\begin{array}{c}\text { Potassium Dose } \\
\left(\mathrm{Kg} \mathrm{ha}^{-1}\right)\end{array}$ & 3.17T-0.46SK-0.48FYM-K & 3.23T-0.46SK \\
\hline
\end{tabular}


Table.4 N, P and K requirement for different yield targets of Urd without using FYM

\begin{tabular}{|c|c|c|c|}
\hline Soil test value $\left(\mathrm{kg} \mathrm{ha}^{-1}\right)$ & \multicolumn{3}{|c|}{ Yield Target (q ha-1) } \\
\hline \multirow{2}{*}{ Alkaline $\mathrm{KMnO}_{4}-\mathrm{N}\left(\mathrm{Kg} \mathrm{ha}^{-1}\right)$} & 20 & 25 & 30 \\
\hline & \multicolumn{3}{|c|}{ Fertilizer nitrogen } \\
\hline 75 & 20.60 & 29.96 & 39.33 \\
\hline 100 & 14.98 & 24.35 & 33.71 \\
\hline 125 & 9.37 & 18.73 & 28.09 \\
\hline 150 & 3.75 & 13.11 & 22.48 \\
\hline Olsen's- $\mathrm{P}\left(\mathrm{Kg} \mathrm{ha}^{-1}\right)$ & \multicolumn{3}{|c|}{ Fertilizer Phosphorus } \\
\hline 15 & 9.93 & 28.26 & 46.58 \\
\hline 20 & - & 7.14 & 25.46 \\
\hline 25 & - & - & 4.34 \\
\hline Ammonium Acetate-K $\left(\mathrm{Kg} \mathrm{ha}^{-1}\right)$ & \multicolumn{3}{|c|}{ Fertilizer Potassium } \\
\hline 100 & 15.04 & 28.41 & 41.78 \\
\hline 125 & 5.43 & 18.80 & 32.17 \\
\hline 150 & - & 9.19 & 22.56 \\
\hline 175 & - & - & 12.95 \\
\hline
\end{tabular}

Table.5 N, P and K requirement for different yield targets of Urd using 10 tones FYM

\begin{tabular}{|c|c|c|c|}
\hline Soil test values $\left(\mathrm{kg} \mathrm{ha}^{-1}\right)$ & \multicolumn{3}{|c|}{ Yield Target (q ha $\left.{ }^{-1}\right)$} \\
\hline \multirow[t]{2}{*}{ Alkaline $\mathrm{KMnO}_{4}-\mathrm{N}$} & 20 & 25 & 30 \\
\hline & \multicolumn{3}{|c|}{ Fertilizer nitrogen } \\
\hline 75 & 10.16 & & 28.89 \\
\hline 100 & 4.55 & & 23.27 \\
\hline 125 & - & 8.29 & 17.66 \\
\hline Olsen's- P & \multicolumn{3}{|c|}{ Fertilizer Phosphorus } \\
\hline 15 & 8.86524 & 27.18985 & 45.5144 \\
\hline 20 & - & 11 & 24.39462 \\
\hline 25 & - & & 3.27 \\
\hline Ammonium Acetate $-\mathrm{K}$ & \multicolumn{3}{|c|}{ Fertilizer Potassium } \\
\hline 100 & 14.05 & 27.42 & 40.79 \\
\hline 125 & 1.44 & 17.81 & 31.18 \\
\hline 150 & - & 8.20 & 21.57 \\
\hline
\end{tabular}


Table.6 Apparent nutrient balance during experiment

\begin{tabular}{|c|c|c|c|c|c|c|c|c|c|}
\hline \multirow[t]{2}{*}{ S1 No } & \multirow[t]{2}{*}{ Particulars } & \multicolumn{2}{|c|}{ Strip I } & \multicolumn{2}{|c|}{ Strip II } & \multicolumn{2}{|c|}{ Strip III } & \multicolumn{2}{|c|}{ Whole field } \\
\hline & & Initial & Post & Initial & Post & Initial & Post & Initial & Post \\
\hline 1. & $\begin{array}{c}\text { Organic } \\
\text { carbon }(\%)\end{array}$ & $\begin{array}{c}0.16-1.20 \\
(0.59)\end{array}$ & $\begin{array}{c}0.46-1.39 \\
(1.02)\end{array}$ & $\begin{array}{c}0.81-1.64 \\
(1.19)\end{array}$ & $\begin{array}{c}0.39-1.22 \\
(0.88)\end{array}$ & $\begin{array}{c}0.39-1.64 \\
(1.03)\end{array}$ & $\begin{array}{c}0.39-1.64 \\
(1.03)\end{array}$ & $\begin{array}{c}0.16-1.20 \\
0.59\end{array}$ & $\begin{array}{c}0.39-1.64 \\
(1.03)\end{array}$ \\
\hline 2. & $\begin{array}{c}\text { Available } \\
\text { nitrogen } \\
\left(\mathrm{kg} \mathrm{N} \mathrm{ha}^{-1}\right)\end{array}$ & $\begin{array}{c}62.72- \\
200.70 \\
(138.50)\end{array}$ & $\begin{array}{c}112.89- \\
388.86 \\
(250.88)\end{array}$ & $\begin{array}{c}112.89- \\
263.42 \\
(145.30)\end{array}$ & $\begin{array}{c}87.80- \\
363.77 \\
(232.06)\end{array}$ & $\begin{array}{c}75.26- \\
213.24 \\
(145.30)\end{array}$ & $\begin{array}{c}100.35- \\
464.12 \\
(267.24)\end{array}$ & $\begin{array}{c}75.26- \\
263.42 \\
(145.25)\end{array}$ & $\begin{array}{c}87.80- \\
464.12 \\
(251.22)\end{array}$ \\
\hline 3. & $\begin{array}{c}\text { Available } \\
\text { phosphorus } \\
\left(\text { kg P ha }^{-1}\right)\end{array}$ & $\begin{array}{c}41.77-60.23 \\
(50.35)\end{array}$ & $\begin{array}{c}2.46-22.17 \\
(16.02)\end{array}$ & $\begin{array}{c}51.49-66.06 \\
(59.18)\end{array}$ & $\begin{array}{c}4.92-21.95 \\
(13.85)\end{array}$ & $\begin{array}{c}38.86- \\
95.20 \\
(61.40)\end{array}$ & $\begin{array}{c}5.6-22.17 \\
(16.68)\end{array}$ & $\begin{array}{c}10.60- \\
67.03 \\
(16.04)\end{array}$ & $\begin{array}{c}2.46- \\
22.17 \\
(14.88)\end{array}$ \\
\hline 4. & $\begin{array}{l}\text { Available } \\
\text { potassium } \\
\left.\text { (kg K ha }^{-1}\right)\end{array}$ & $\begin{array}{l}60.48- \\
151.87 \\
(97.38)\end{array}$ & $\begin{array}{c}116.2- \\
185.92 \\
(142.22)\end{array}$ & $\begin{array}{c}69.88-227.13 \\
(138.09)\end{array}$ & $\begin{array}{c}111.55- \\
260.28 \\
(180.49)\end{array}$ & $\begin{array}{c}100.8- \\
227.13 \\
(166.93)\end{array}$ & $\begin{array}{c}102.25- \\
241.69 \\
(144.39)\end{array}$ & $\begin{array}{c}60.48- \\
227.13 \\
(135.16)\end{array}$ & $\begin{array}{c}102.25- \\
260.28 \\
(154.80)\end{array}$ \\
\hline
\end{tabular}

Table.7 Yield of urd seed under various treatments

\begin{tabular}{|c|c|}
\hline Treatment details $\left(\mathrm{N}: \mathrm{P}_{2} \mathrm{O}_{5}: \mathrm{K}_{2} \mathrm{O}: \mathrm{FYM}\right)$ & Yield (q/ha) \\
\hline $\mathrm{T}_{1}=$ Control & 12.98 \\
\hline $\mathrm{T}_{2}=\mathrm{GRD}$ & 14.27 \\
\hline $\mathrm{T}_{3}=\mathrm{TYR}_{1}$ & 15.57 \\
\hline $\mathrm{T}_{4}=\mathrm{TYR}_{1}+5 \mathrm{t} / \mathrm{ha} \mathrm{FYM}(\mathrm{IPNS})$ & 16.87 \\
\hline $\mathrm{T}_{5}=\mathrm{TYR}_{1}+10 \mathrm{t} / \mathrm{ha} \mathrm{FYM}(\mathrm{IPNS})$ & 18.60 \\
\hline $\mathrm{T}_{6}=\mathrm{TYR}_{2}$ & 18.17 \\
\hline $\mathrm{T}_{7}=\mathrm{TYR}_{2}+5 \mathrm{t} / \mathrm{ha} \mathrm{FYM}$ (IPNS) & 15.15 \\
\hline $\mathrm{T}_{8}=\mathrm{TYR}_{2}+10 \mathrm{t} / \mathrm{ha} \mathrm{FYM}(\mathrm{IPNS})$ & 15.57 \\
\hline $\mathrm{T}_{9}=\mathrm{TYR}_{1}+\mathrm{Zn}$ & 32.45 \\
\hline $\mathrm{T}_{10}=\mathrm{TYR}_{1}+\mathrm{B}$ & 16.87 \\
\hline C.D. at $5 \%$ & 0.409 \\
\hline $\mathrm{SE}(\mathrm{m})$ & 0.137 \\
\hline
\end{tabular}

Table.8 Economics of verification trial on urd

\begin{tabular}{|c|c|c|c|c|c|c|c|}
\hline Treatments & $\begin{array}{c}\text { Fertilizer } \\
\text { dose N-P-K } \\
\text { FYM (kg/ha) }\end{array}$ & $\begin{array}{l}\text { Actual } \\
\text { yield } \\
(\mathrm{kg} / \mathrm{ha})\end{array}$ & $\begin{array}{l}\text { Additional } \\
\text { yield } \\
\text { (kg/ha) }\end{array}$ & $\begin{array}{c}\text { Value of } \\
\text { additional } \\
\text { yield (Rs.) }\end{array}$ & $\begin{array}{c}\text { Cost of } \\
\text { fertilizer } \\
\text { (Rs.) }\end{array}$ & $\begin{array}{l}\text { Net benefit } \\
\left(\text { Rs. ha }{ }^{-1}\right)\end{array}$ & $\mathrm{B} / \mathrm{C}$ ratio \\
\hline$T_{1}=$ Control & $0-0-0$ & 1298 & - & - & ;- & - & - \\
\hline $\mathbf{T}_{2}=\mathbf{G R D}$ & $20-40-60$ & 1947 & 649 & 51920 & 3634 & 48286 & 13.24 \\
\hline$T_{3}=$ TYR1 & $19-23-19$ & 1557 & 259 & 20720 & 1832.02 & 18887.98 & 10.30 \\
\hline$T_{4}=T Y R_{1}+5 T / h a$ & $18-22-16$ & 1687 & 389 & 31120 & 1699.16 & 29420.84 & 17.31 \\
\hline$T 5=T_{Y} R_{1}+10 t / h a$ FYM (IPNS) & $16-20-15$ & 1860 & 562 & 44960 & 1550.24 & 43409.76 & 28.01 \\
\hline$T_{6}=T_{Y R_{2}}$ & $4-65-30$ & 1817 & 519 & 41520 & 3931.16 & 37588.84 & 9.56 \\
\hline $\mathrm{T}_{7}=\mathrm{TYR}_{2}+5 \mathrm{t} / \mathrm{ha}$ FYM (IPNS) & $25-65-30$ & 1515 & 217 & 17360 & 4223.9 & 13136.1 & 3.10 \\
\hline$T_{8}=T_{Y R_{2}}+10 t / h a$ FYM (IPNS) & $24-65-30$ & 1557 & 259 & 20720 & 4209.96 & 16510.04 & 3.92 \\
\hline$T_{9}=T Y R_{1}+Z n$ & $19-23-19$ & 1557 & 259 & 20720 & 1832.02 & 18887.98 & 10.30 \\
\hline$T_{10}=T_{Y R}+B$ & 19-23-19 & 1687 & 389 & 31120 & 1832.02 & 29287.98 & 15.98 \\
\hline
\end{tabular}


Fig.1 Nitrogen requirement of urd at different soil test value and yield target without using FYM

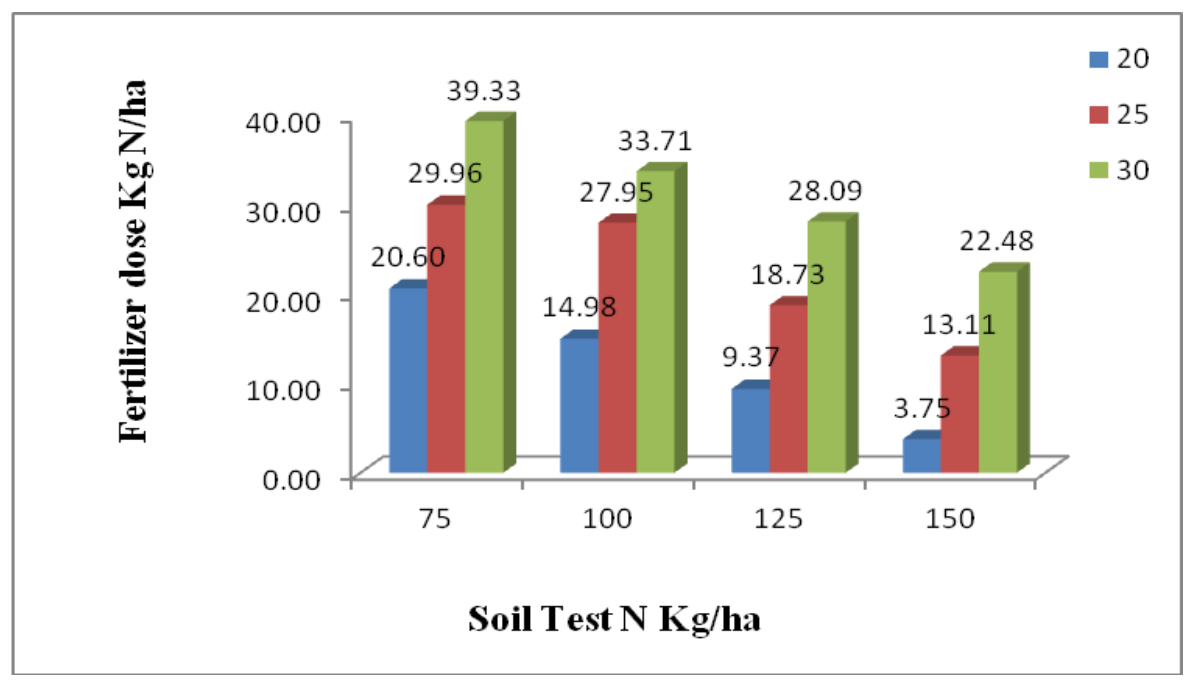

Fig.2 Phosphorus requirement of urd at different soil test value and yield target without using FYM

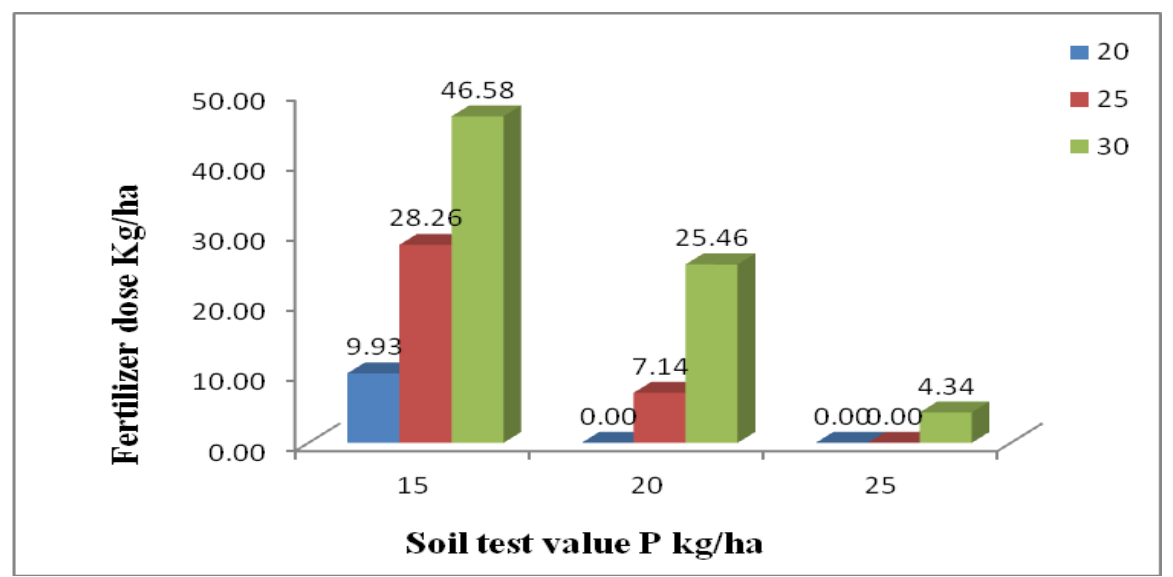

Fig.3 Potassium requirement of urd at different soil test value and yield target without using FYM

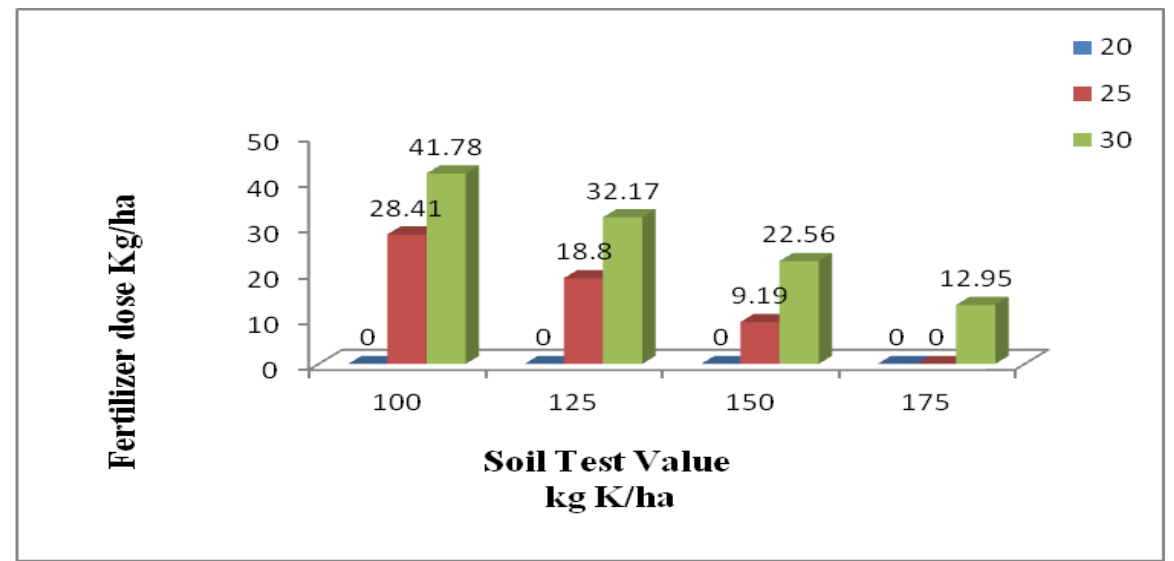


Fig.4 Nitrogen requirement of Urd at different soil test value and yield target

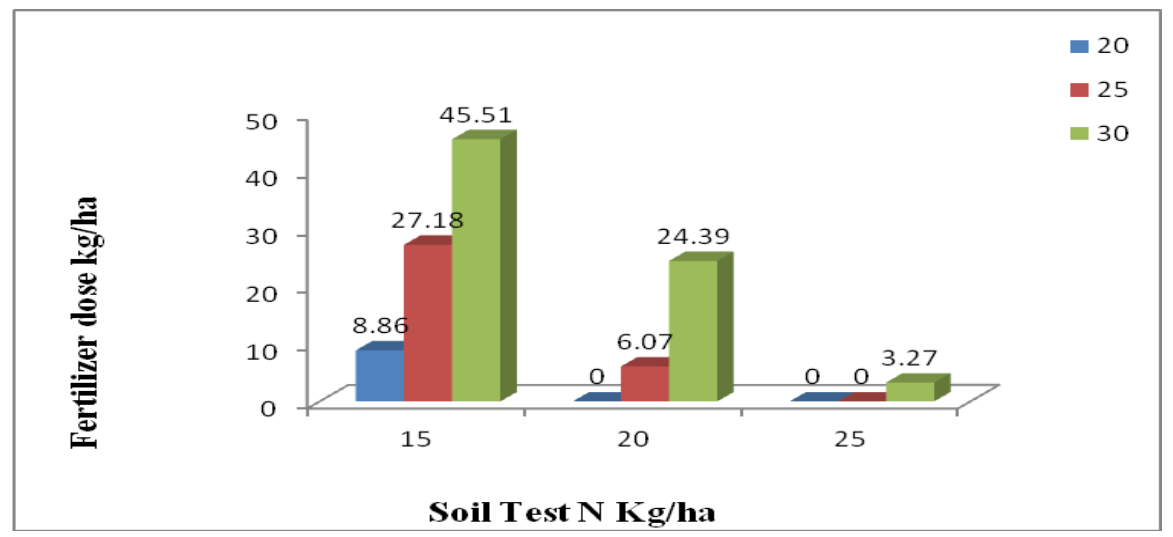

Fig.5 Phosphorus requirement of Urd at different soil test value and yield target

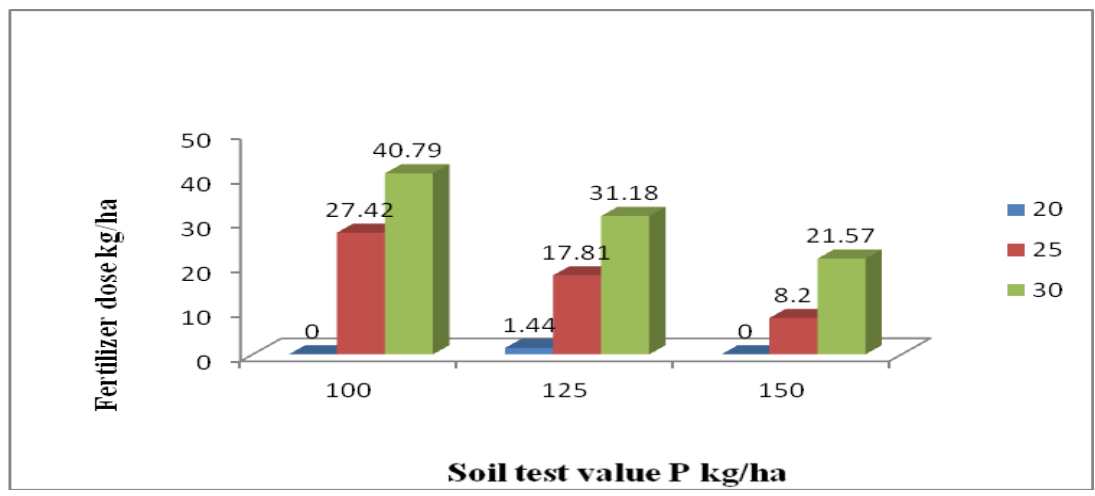

Fig.6 Potassium requirement of Urd at different soil test value and yield target

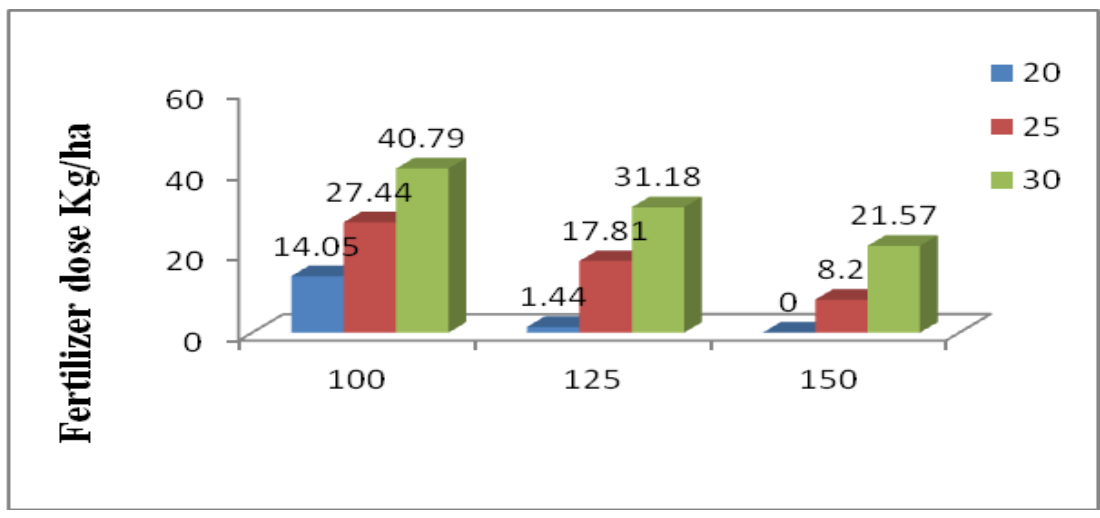

Strip wise variation ranged from 112.89 to 388.86 with a mean of 250.88 in strip I, 87.80 to $363.77 \mathrm{~kg} \mathrm{~N}^{-1}$ with a mean of $232.06 \mathrm{~kg}$ $\mathrm{N} \mathrm{ha}^{-1}$ in strip II and 100.35 to 464.12 with a mean of $267.24 \mathrm{~kg} \mathrm{~N} \mathrm{ha}^{-1}$ in strip III. The average value of Nitrogen was highest in strip
III followed by strip I and strip II, respectively.

Available Phosphorus content of the entire experimental field ranged from 2.46 to $22.17 \mathrm{~kg} \mathrm{P}$ $\mathrm{ha}^{-1}$ with a mean value of $14.88 \mathrm{~kg} \mathrm{Pha}^{-1}$. 
Strip wise range varied from 2.46 to 22.17 with a mean value of $16.02 \mathrm{~kg} \mathrm{Pha}^{-1}$ in strip I, 4.92 to 21.95 with a mean value of $13.85 \mathrm{~kg} \mathrm{P}$ $\mathrm{ha}^{-1}$ in strip II and 5.6 to $22.17 \mathrm{~kg} \mathrm{P} \mathrm{ha}^{-1}$ with a mean value of $16.68 \mathrm{~kg} \mathrm{P} \mathrm{ha}^{-1}$ in strip III. The average value of Phosphorus was highest in strip III followed by strip I and strip II, respectively. These post harvest values used for fertilizer recommendation by targeted yield approach for next crop in the cropping system.

Available Potassium content of the entire experimental field ranged from 102.25 to $260.28 \mathrm{~kg} \mathrm{P} \mathrm{ha}^{-1}$ with a mean value of 154.80 $\mathrm{kg} \mathrm{K} \mathrm{ha}^{-1}$. Strip wise range varied from 116.2 to 185.92 with a mean value of $142.22 \mathrm{~kg} \mathrm{~K}$ ha $^{-1}$ in strip I, 111.5 to 260.28 with a mean value of $180.49 \mathrm{~kg} \mathrm{~K} \mathrm{ha}^{-1}$ in strip II and 102.2 to $241.69 \mathrm{~kg} \mathrm{~K}^{-1}$ with a mean value of $144.39 \mathrm{~kg} \mathrm{P} \mathrm{ha}^{-1}$ in strip III. The average value of Phosphorus was highest in strip II followed by strip III and strip I, respectively. These post harvest values used for fertilizer recommendation by targeted yield approach for next crop in the cropping system (Table $6)$.

\section{Verification trial for Urd}

The verification trials are important for the calibration of results obtained on research farm are required to be tested for their validity. Verification trials have a great demonstration value of showing the importance of soil testing for fertilizer recommendations to farmers and result in wider acceptability of soil testing to the farming community. The objective of these trials is (i) to test the validity of results obtained from the main experiment before recommendation to the extension agencies and (ii) to show the farmers the greater profitability of the soil test based fertilizer recommendation than general recommended dose. The validity of the targeted yield equations developed for urd during Rabi season in 2014-15 was tested in Rabi season of 2014-15 by conducting verification trials on the same location. The results obtained in verification trial are presented in table 7 Among the treatments, all treatments gave significantly higher yield over control (Table 7). Among the treatments $\mathrm{TYR}_{1}+\mathrm{Zn}\left(\mathrm{T}_{9}\right)$ gave a significantly higher yield as compared to general recommendation $\left(\mathrm{T}_{2}\right)$. The controls $\left(T_{1}\right)$ were less efficient in producing seed yield of Urd. Fertilizer application based on target yield approach was found to be superior over general recommended dose (GRD). An increase in profits over farmers' practice and general recommended dose of fertilizers was observed with increasing yield targets in urd and other pulse crops with or without FYM which might be due to the efficiency factor tended to increase in crop yield (Kadam and Sonar, 2006, Hariprakash and Subramanian, 1994 and Anonymus, 2000).

$\mathrm{B} / \mathrm{C}$ ratio was reported to follow the order among the treatment:

\section{$T_{5}>T_{4}>T_{2}>T_{10}>T_{9}=T_{3}>T_{6}>T_{8}>T_{7}>$}

Therefore, hence concluded, these fertilizer adjustment equations developed for the integrated nutrient management system are useful for prescribing fertilizer doses to Urd for the tarai region of Mollisols and adjoining areas having similar soil and agro-climatic conditions. Keeping in view the poor socioeconomic condition of the farmers with very low income, a yield target of $25 \mathrm{q} \mathrm{ha}^{-1}$ was taken so that even at the very low input cost farmers can achieve economical yield target

\section{References}

Jackson M.L. (1973) Soil Chemical Analysis. Prentice Hall of India Pvt. Ltd., New Delhi, 498pp

Kadam, B.S. and Sonar, K.R. 2006. Targeted Yield Approach for assessing the 
fertilizer requirement of Onion in Vertisols. J. Indian Soc. Soil Sci., 54:513-515.

Kimetu, M., D.N. Mugendi., C.A. Palm, P.K. Mutro., C.N. Gachengo., S. Nandwa, and B. Kungu. 2004. African network on soil biology and fertility. Pp-207224.

Ladha J.K., Dave D., Pathak H., Padre A.T., Yadav R.L. And Singh B. (2003) Field Crop Research., 81, 158-180.

Mahala, C.P.S. Dadheech, R.C. And Kulhari, R.K., (2001) Effect of plant growth regulators on growth and yield of blackgram (Vigna Mungo) at varying levels of phosphorus. Crop Res.,
18(1): 163-165.

Ramamoorthy, B., Narsimham., R.L. and Dinesh, R.S. 1967. Fertilizer application for specific yield targets of Sonora 64. Indian Farming 17, 43-45.

Reddy, K.C.K., Velayutham, M. And Maruthi Sankar, G.R. 1994. Soil test based prescriptions for yield targets of crops extension. Bulletin of All India Coordinated Research Project on Soil Test Crop Response Correlation

Subbiah, B.V. and Asija, G.L. 1956. A rapid procedure for the determination of available nitrogen in soils. Curr. Sci. 25: 259-262.

\section{How to cite this article:}

Varun Tripathi, Ajaya Srivastava, S.P. Gangwar and Singh, R.K. 2018. Soil Test Crop Response Based Fertilizer Prescription for Urd Grown on Mollisol of Uttarakhand. Int.J.Curr.Microbiol.App.Sci. 7(07): 90-101. doi: https://doi.org/10.20546/ijcmas.2018.707.011 